\title{
Management of pain in patients with temporomandibular disorder (TMD): challenges and solutions
}

This article was published in the following Dove Press journal: Journal of Pain Research

\author{
Alfonso Gil-Martínez ${ }^{1-3}$ \\ Alba Paris-Alemany ${ }^{1-4}$ \\ Ibai López-de-Uralde- \\ Villanueval-3 \\ Roy La Touche ${ }^{1-4}$ \\ 'Department of Physiotherapy, \\ 2Motion in Brains Research Group, \\ Instituto de Neurociencias y Ciencias \\ del Movimiento, Centro Superior \\ de Estudios Universitarios La Salle, \\ Universidad Autónoma de Madrid, \\ ${ }^{3}$ Hospital La Paz Institute for Health \\ Research, IdiPAZ, ${ }^{4}$ Institute of \\ Neuroscience and Craniofacial Pain \\ (INDCRAN), Madrid, Spain
}

\begin{abstract}
Thanks to advances in neuroscience, biopsychosocial models for diagnostics and treatment (including physical, psychological, and pharmacological therapies) currently have more clinical support and scientific growth. At present, a conservative treatment approach prevails over surgery, given it is less aggressive and usually results in satisfactory clinical outcomes in mild-moderate temporomandibular disorder (TMD). The aim of this review is to evaluate the recent evidence, identify challenges, and propose solutions from a clinical point of view for patients with craniofacial pain and TMD. The treatment we propose is structured in a multimodal approach based on a biobehavioral approach that includes medical, physiotherapeutic, psychological, and dental treatments. We also propose a new biobehavioral model regarding pain perception and motor behavior for the diagnosis and treatment of patients with painful TMD. Keywords: biobehavioral, review, temporomandibular disorders, biobehavioral orofacial pain, multimodal approach, motor behavior, disability
\end{abstract}

\section{Introduction}

According to health sciences definitions, temporomandibular disorder (TMD) comprises a variety of conditions affecting the anatomy and functional characteristics of the TM joint (TMJ). Factors contributing to TMD complexity are related to dentition, clenching, and other related systems that frequently provoke symptoms of muscular, articular, and periarticular pain. ${ }^{1}$

Orofacial pain is defined as a pain manifested in the face or oral cavity, including such disorders as TMD, which are a major cause of nonodontogenic orofacial pain. ${ }^{2,3}$ TMD has considerable prevalence, with significant impact on physical and psychosocial factors. ${ }^{2}$ Its prevalence has been reported to be between $3.7 \%$ and $12 \%$, and is three to five times more frequent in women. ${ }^{4}$ TMD also contributes to a high proportion of socioeconomic costs, which are usually associated with comorbidities, such as depression and other psychological factors. ${ }^{5-7}$ Also, the loss of work and work productivity is a major issue to consider in TMD patients being treated early on, and it requires significant public education.

\section{Before 2000}

Although before the 1980s, malocclusion and other related factors were considered fundamental and key causes of TMD, during this decade authors began to publish critical articles on these subjects. ${ }^{8}$ In current clinical practice, orthodontic treatments are still used to treat TMD; however, it was established in the 1990s that the role of
Correspondence: Alfonso Gil-Martínez Centro Superior de Estudios Universitarios La Salle, 10 Calle de la Salle, Madrid 28023, Spain

$\mathrm{Tel}+34666137908$

Email fongilmar@gmail.com 
malocclusion in TMD is very limited or nonexistent, ${ }^{9}$ and thus these disorders should not be treated with orthodontics. ${ }^{10}$

\section{Decade 2000 to 2010}

During the 2000-2010 decade, invasive treatments and surgical options for TMD came into use. However, by the end of this decade, clinical experience and several studies included in systematic reviews, such as Guo et al, reported a lack of evidence supporting the use of arthrocentesis or arthroscopy for TMD treatment. ${ }^{11}$

\section{From 2010}

Although the cognitive and behavioral profiles of patients with TMD have been debated for some years, ${ }^{11}$ it was in the present decade that health professionals began to propose behavior-based therapies ${ }^{12}$ as a promising treatment related to cost-effectiveness. ${ }^{13}$ This paradigm has since been changing and developing a wider focus, leaving behind the biomedical structural model. Thanks to advances in neuroscience, ${ }^{14,15}$ biopsychosocial models for diagnostics and treatment (including physical, psychological, and pharmacological therapies) currently have more clinical support and scientific growth. ${ }^{16,17}$

\section{Classification and research diagnostic criteria for temporomandibular disorders}

International classifications have been updated in recent decades, thus adapting to new clinical diagnoses and research. The etiology of TMD is multifactorial, which is due to related functional, structural, and psychological factors. ${ }^{18-20}$ In regard to the clinical presentation of TMD, one of the most frequent symptoms is pain. Pain can affect such areas as ears, eyes, and/or throat, producing neck pain, facial pain, and headaches. ${ }^{21}$ Among the physical factors, inflammatory problems, such as traumatic secondary synovitis, infection, and irritation, can be found. TMD can also be associated with disk dysfunction, with or without reduction. ${ }^{22}$

The Research Diagnostic Criteria for TMD (RDC/TMD) have been one of the most commonly used and recognized classifications by the international scientific community for diagnosis, evaluation, and categorization of TMD to date. Their importance is highlighted by the fact that they have been translated into various languages. ${ }^{23,24}$ The RDC/TMD are based on a biobehavioral model of pain, including two main axes: physical signs and symptoms (axis I) and psychological and disability factors (axis II). Included in axis I are painful myofascial disorders, disk subluxation, or luxation and arthritis or arthrosis, ${ }^{25}$ given painful myofascial disorders are included in the most frequent diagnoses observed in the literature. ${ }^{25}$ The most recent published version of this classification was in 2014, named Diagnostic Criteria for TMD (DC/TMD), ${ }^{26}$ and aimed to improve the sensibility and specificity of the previous RDC/TMD through more comprehensive instruments for axis I and axis II that can be used by researchers and clinicians.

\section{Neurophysiology of trigeminal sensory system}

The trigeminal nerve, or cranial $\mathrm{V}$ nerve, is considered a mixed-function nerve (sensory, motor, and autonomic) ${ }^{27}$ and a major cranial nerve. ${ }^{28}$ This nerve is termed "trigeminal" due to its three main branches: the ophthalmic nerve $\left(\mathrm{V}_{1}\right)$, the maxillary nerve $\left(\mathrm{V}_{2}\right)$, and the mandibular nerve $\left(\mathrm{V}_{3}\right)$. Sensitive axons of the trigeminal nerve innervate the majority of cranial and facial tissues, except the posterior area of the cranium, the mandibular angle, part of the external auditory canal and pavilion, and part of the pharynx. ${ }^{29}$

Although the primary innervation patterns and the nerve signals are similar throughout the body, the craniofacial region has some particularities. Craniofacial innervation depends on several anatomic and functional structures of primary afferent neurons emanating from the trigeminal ganglion (and other cranial nerves). There are certain differences in the neurons and the dorsal root ganglia of the spinal cord. For example, the relationship between myelinated afferent fibers (A) and unmyelinated afferent fibers (C) is closer in the trigeminal nerve than in the spinal nerves. Spinal nerves present relatively few $\mathrm{C}$ fibers. ${ }^{30}$ This situation could generate a higher mean velocity of conduction in trigeminal areas. In addition, cranial region distances to the neuronal body are shorter than in the rest of the body. ${ }^{31}$

On the other hand, cranial peripheral nerves have fewer efferent sympathetic axons than spinal nerves. Some authors have postulated that this peculiarity could have relative influence on painful states maintained by the sympathetic nervous system itself in the trigeminal region. ${ }^{32}$ Other sympathetic differences between the trigeminal area and the rest of the body are the intracranial and cutaneous blood vessels. In the trigeminal area, these vessels receive both parasympathetic and sympathetic innervation; however, in the segmental levels parasympathetic innervation is infrequent or nonexistent. ${ }^{33}$

\section{Physiopathology of TMD}

Trigeminal primary afferent fibers are present in the craniofacial tissues as free nerve endings functioning as nociceptors that can activate through mechanical, thermal, or chemical 
stimuli. Their activation can result in the excitation of smalldiameter and slow fibers $(\alpha \delta$ or $C) .{ }^{34-36}$ Some neurochemical components (eg, substance P, 5-HT, prostaglandins, and bradykinins) are involved in this peripheral activation by nociceptive stimulation. These substances are present in the peripheral sensitization process, and could thus enhance nerve sensitivity after minimum injury. This sensitization of nociceptive endings is a peripheral mechanism that as an alert system helps to protect injured tissues from repeated stimuli. ${ }^{37,38}$

The fact that "nociceptive-specific" and "wide dynamic range" neurons located in the trigeminal subnucleus caudalis are excited by nociceptive stimuli (in both cases) and nonnociceptive stimuli (in wide dynamic range) should be taken into account. ${ }^{36}$ The majority of these neurons can also be excited by other inputs from the meninges, vessels, oral tissues, TMJ, and masticatory muscles. ${ }^{25,27,29}$ These inputs have widely convergent patterns, explaining a poor and deep pain location, as well as the diffusion of referred pain, which is a typical condition in TMJ pain and its associated muscles. ${ }^{36,38,39}$ The aim of this review is to evaluate the recent evidence, identify challenges, and propose solutions from a clinical point of view for patients with craniofacial pain and TMD.

\section{Management of TMD}

A suitable therapeutic approach for TMD should be aimed at alleviating the main signs and symptoms of this condition. ${ }^{40}$ The most relevant signs of TMD are the presence of joint sounds (clicking and crepitation), reduced mouth opening, and disrupted jaw movements. ${ }^{21,41}$ However, pain is the primary problem of this pathology, and it is typically the reason these patients request medical care. ${ }^{17,42}$ Also, it is likely the reason that most studies have been aimed at evaluating the effectiveness of various intervention measures related to pain as the main variable. ${ }^{43}$

Conservative treatments for TMD include medication, physiotherapy, occlusal splints, self-management strategies, and interventions based on cognitive behavioral approaches. ${ }^{44-49}$ At present, a conservative treatment approach prevails over surgery, given it is less aggressive and usually results in satisfactory clinical outcomes in mild-moderate TMD. ${ }^{48,50-52}$ In fact, the evidence for the greatest effectiveness of surgical versus conservative intervention to reduce short-term pain in arthrogenic TMD is controversial and inconclusive. ${ }^{53-55}$ Indications for the application of each of the interventions, as well as their potential effects for the treatment of patients with TMD, are described in the following sections.

\section{Oral and topical pharmacotherapy}

The pharmacological treatment of the patients with TMD is usually empirical. Although several medications are typically prescribed for the treatment of TMD, many lack evidence for this specific pathology; ${ }^{56}$ however, they have proven their effects in other musculoskeletal conditions. The most commonly used drugs include nonsteroidal anti-inflammatory drugs (NSAIDs), corticoids, analgesics, muscle relaxants, anxiolytics, opiates, tricyclic antidepressants (TCAs), gabapentin, and lidocaine patches. ${ }^{57-60}$ Some of these medications are used to treat the joint pain of the TMD, and others are more effective for treating muscle pain.

NSAIDs have proven their effect in reducing pain in the TMJ. One of the most frequently used NSAIDs is sodium diclofenac, which can reduce joint pain at a dose of $50 \mathrm{mg}$ twice/thrice daily. ${ }^{49,61}$ Another NSAID used is naproxen sodium, which has been demonstrated to reduce joint pain compared with placebo. Significant differences have been shown after 3 weeks of treatment (500 $\mathrm{mg}$ twice a day), and a significant improvement in clinical signs and symptoms of TMD was obtained compared with celecoxib and placebo. ${ }^{62}$ Piroxicam $20 \mathrm{mg}$ once a day for 10 days results in greater TMJ pain reduction at 30-day follow-up..$^{63}$ Another substance not very well known but well tolerated is palmitoylethanolamide (300-1,200 mg daily up to 120 days) ${ }^{64}$ which appears to have an analgesic and anti-inflammatory effect in patients with TMD. ${ }^{65,66}$

These results suggest that long-term treatment is needed to obtain the maximal effects of all these drugs, which sometimes become evident only after several weeks of treatment. NSAIDs have-well known adverse effects, however, such as exacerbation of hypertension, gastrointestinal effects ranging from dyspepsia to ulceration, and worsening of renal function, which makes analyzing the clinical situation of each patient extremely important to establish the best individual treatment.

A different approach to NSAID intake for avoiding its systemic absorption is its topical administration in creams or ointments over the TMJ to reduce pain. The application of four doses a day of topical diclofenac combined with dimethyl sulfoxide to improve its absorption is recommended ${ }^{67}$ Topical diclofenac has been suggested to achieve local concentrations significant enough to inhibit proinflammatory prostaglandin $\mathrm{E}_{2}$ production and also competitively inhibit the NMDA subtype of the glutamate receptor found in TMJ nociceptors. ${ }^{68}$

For the treatment of muscle pain in myofascial TMD muscle, such relaxants as diazepam and cyclobenzaprine 
are commonly used. ${ }^{61,69}$ Diazepam has shown better effects than ibuprofen for chronic orofacial muscle pain ${ }^{71}$ and the same effects as placebo for reducing TMD pain. ${ }^{71} \mathrm{~A}$ recent meta-analysis concluded that cyclobenzaprine had a positive effect on TMD muscle pain in the short term ${ }^{61}$ through its effect over local spasms and associated acute pain; it was even more effective than clonazepam in improving jaw pain upon awakening. ${ }^{72}$ The NSAID sodium diclofenac, both by itself and in combination with acetaminophen, carisoprodol, and caffeine, has been proven to have a more rapid positive effect on masticatory muscle pain compared with placebo. ${ }^{73}$

TCAs have been proposed by some authors for myofascial masticatory chronic pain, particularly amitriptyline and nortriptyline, as first-line treatments for myofascial pain with referral, with low doses of $10-35 \mathrm{mg}$ per day. ${ }^{74,75}$ Others propose a second-line treatment of gabapentin for nonresponders or for those who do not tolerate TCAs. ${ }^{75,76}$

\section{Injected pharmacotherapy}

In a recent review, results supported the use of injections of the corticosteroid $\beta$-methasone or sodium hyaluronate for TMJ pain. ${ }^{53,61}$ The corticosteroid might have an antiinflammatory effect on the joint, and the hyaluronate could improve the joint's lubrication, but both could also help to dilute local inflammatory substances. Inferior or double TMJ-space injection is recommended over the superior-space injection technique. ${ }^{77}$

Regarding botulinum toxin (BTX) injections to the masticatory muscles, a systematic review revealed controversial results for BTX therapy. Of the five studies included, two obtained a significant reduction in pain, one showed equal effects compared with masticatory manual therapy, and two showed no significant differences for BTX compared with placebo. ${ }^{78}$ More research is needed to assess the possible long-term negative effects of BTX on the infiltrated muscles. Basic research has shown that the size of the muscle recovered, but not the contractile function, after 1 year of BTX injections. ${ }^{79}$ Also, when comparing BTX with placebo injection for trapezius muscle pain, there were no differences in pain-intensity measurement. ${ }^{80}$

\section{Surgical interventions}

Among the surgical options, two of the most frequently used techniques for internal derangements of the TMJ or degenerative pathology are arthrocentesis based on articular lavage with or without injection of pharmaceuticals and arthroscopy. There are no differences regarding pain and mandibular function when comparing arthroscopy with arthrocentesis $;^{81,82}$ however, there is a lack of evidence to support arthrocentesis as a better therapeutic intervention than nonsurgical interventions. ${ }^{83,84}$ For internal derangement of the TMJ, medical management or rehabilitation is recommended over other surgical options, ${ }^{85}$ patients with symptomatic disk displacement without reduction should be treated with the simplest and least invasive intervention. ${ }^{86}$ Furthermore, there is growing evidence supporting the benefit of platelet-rich plasma injections over hyaluronate combined with arthrocentesis for TMJ osteoarthritis; however, more clinical trials are needed. ${ }^{87-89}$

\section{Dental management}

Two approaches are usually proposed by odontologists to treat their TMD patients: orthopedic stabilization therapy and occlusal therapy. Splint therapy is frequently used for the first method group; in the second method, orthodontics and occlusal adjustment are commonly used to achieve a definite correct stable occlusion. According to Varga, signs and symptoms of TMD could not be associated with specific types of malocclusion. ${ }^{90}$ This statement, together with published reports stating insufficient evidence, precludes us from recommending to our patients an orthodontic intervention or occlusal adjustment to treat TMD. ${ }^{91,92}$

On the other hand, splint therapy is one of the most commonly proposed conservative treatments for TMD pain associated with bruxism and also for internal derangements. It is not clear whether the use of a stabilization splint can be beneficial for reducing pain in TMD, ${ }^{93}$ given its therapeutic effect remains controversial; however, it appears to have an undeniable placebo effect for pain management. ${ }^{94} \mathrm{~A}$ transient effect of reduction in electromyographic activity of the masticatory muscles has been demonstrated, which did not last more than 2 weeks. ${ }^{95,96}$ Occlusal splints are recommended to prevent dentition damage from tooth grinding. ${ }^{97,98}$

\section{Physical therapy}

Physical therapy plays a prominent role in the treatment of TMD. ${ }^{45,46,99}$ This therapeutic discipline aims to relieve pain, reduce inflammation, and restore motor function using a wide range of techniques, including manual therapy (eg, joint mobilization/manipulations, soft-tissue mobilization), therapeutic exercise, electrotherapy (eg, low-level laser therapy [LLLT], transcutaneous electrical nerve stimulation [TENS], therapeutic ultrasound, shortwave), dry needling (DN), and acupuncture. ${ }^{45,47}$ 


\section{Manual therapy}

Manual therapy for TMD, regardless of its origin, should include joint mobilization and soft-tissue techniques, with the aim of improving function and reducing pain symptoms. ${ }^{52,100}$ These techniques can trigger neurophysiological mechanisms responsible for pain relief and reduction of muscle activity. ${ }^{101-103}$

According to the literature, some authors also consider it relevant to apply these types of techniques to the cervical region, especially in the upper cervical spine..$^{52,100}$ The demonstrated efficacy of the articular upper cervical mobilizations in reducing pain and increasing mandibular range of motion $(\mathrm{ROM})^{52,100}$ could be due to the neuroanatomical connection between these two segments at the trigeminal-cervical complex $^{36,104}$ or the biomechanical relationship between the cervical and orofacial regions. ${ }^{105,106}$

A debate among manual therapists concerns which approach is the best articular technique for treating the cervical spine. Authors have recommended cervical mobilizations, which have been shown to be more effective in reducing orofacial pain over manipulations. ${ }^{52,100,107}$ They are safer, and produce similar effects at the cervical spine. ${ }^{108-110}$

\section{Therapeutic exercise}

Exercise focused on improving motor control and endurance of masticatory muscles is effective in alleviating the symptoms of patients with TMD. ${ }^{52}$ However, exercise does not produce greater pain relief than other interventions, ${ }^{52}$ such as TENS, ${ }^{111}$ occlusal splints, ${ }^{112-114}$ patient education, ${ }^{115,116}$ and acupuncture. ${ }^{117}$ It is important to keep in mind, however, that the exercises used in randomized controlled trials have been heterogeneous, including stretching, lingual and masticatory relaxation, and coordination exercises, among others. ${ }^{45,52}$ This aspect, added to the lack of a clear dosage regarding intensity, duration, and frequency, and the low methodological quality of the randomized controlled trials makes it difficult to draw conclusions. ${ }^{45,52}$ Nevertheless, although the superiority of the exercises cannot be assured, there is a favorable tendency when compared with other active treatments, ${ }^{52}$ which might justify its use.

Therefore, we consider that therapeutic exercise could obtain superior results to other treatments if a program with motor-control exercises and endurance of the cervical and masticatory muscles is applied. Although some studies included cervical exercises, most were aimed at increasing the ROM (mobility and stretching exercises), but none intended to improve the resistance of cervical spine stabilizers. ${ }^{52}$
Stabilizing muscles are essential to maintaining good postural control and helping to prevent the adoption of a forward head position. ${ }^{118-120}$

\section{Manual therapy and exercise}

A combined intervention of manual therapy and exercise is effective in alleviating the symptoms of patients with TMD, further enhancing the effects of both interventions in isolation. ${ }^{52}$ These findings match those observed for cervical pain, ${ }^{121}$ which can be explained by the summation of the hypoalgesic effects of manual therapy ${ }^{104}$ along with the benefits of exercise, including improvements in physical condition, and the adoption of an active role by the patient in their treatment. ${ }^{122-125}$ On the other hand, although it is effective to administer this combined intervention in the cervical region, greater benefits are obtained when applied in both the orofacial and cervical regions..$^{52}$ Therefore, we consider it fundamental that physiotherapy treatment combine manual therapy with a program of therapeutic exercises aimed at restoring motor control and resistance of the masticatory and cervical musculature to improve the clinical condition of patients with TMD.

\section{Dry needling and acupuncture}

Few studies were found that applied dry needling (DN) for TMD. ${ }^{126-129}$ This intervention is used for treating local and referred pain produced by myofascial trigger points. ${ }^{130}$ From these few studies, we conclude that $\mathrm{DN}$ results in a reduction in pain and improvements in mandibular function of patients with myofascial TMD. ${ }^{126-129}$ The effects of DN are comparable to the effects obtained by injection of the trigger points with lidocaine and corticosteroid. ${ }^{131}$

Acupuncture is a good therapeutic modality for shortterm pain relief in patients with myofascial TMD, but not in those cases in which there is a limitation of mandibular movement. ${ }^{132,133}$ At present, the mechanisms responsible for the analgesia produced by acupuncture are unknown, but appear to be based on the spinal and supraspinal release of serotonin, ${ }^{134,135}$ endogenous opioids, ${ }^{136-138}$ and other neurotransmitters with anti-inflammatory actions. ${ }^{139,140}$ The application of acupuncture is preferable by selecting points in the orofacial region, rather than distal to it, because enhanced effects are obtained in this manner, ${ }^{141,142}$ and not necessarily by selecting the standard acupuncture points. ${ }^{143}$ These findings can be explained by the participation of peripheral opioid receptors in the analgesic process, given these receptors generate blockage of the painful input locally 
and unsystemically, and by the noxious stimulus itself independently of where it is applied. ${ }^{143,144}$ In fact, there are no differences when acupuncture and DN are compared with placebo that includes skin perforation. ${ }^{132,133,145}$

\section{Electrotherapy}

Current evidence does not support the use of electrotherapy for pain relief in patients with TMD. ${ }^{45,53}$ In particular, various types of electrotherapy, such as pulsed radiofrequency energy, TENS, and LLLT, show no better results than their respective placebos in the treatment of TMD. ${ }^{45,53}$ However, the application criteria need to be homogenized in order to establish definitive conclusions, especially for the application of LLLT, given contradictory results are observed depending of the type of TMD, as well as the choice of parameters, such as intensity and frequency. ${ }^{146}$ Regarding functional improvement, LLLT has proven effective in increasing mandibular ROM. ${ }^{146}$ This effect could be due to a reduction in inflammation by suppressing cyclooxygenase, which would allow greater mobility to the joint. ${ }^{147}$ However, LLLT's mechanisms of action are not yet fully understood.

\section{Cognitive behavioral therapy}

Patients with chronic TMD usually present associated psychological factors that should be managed with specific interventions. Cognitive behavioral therapy is one of the treatments proposed to manage patients' thoughts, behaviors, and/or feelings that might exacerbate pain symptoms. It is a noninvasive therapy and unlikely to have adverse effects. ${ }^{148}$ The literature reports that cognitive behavioral therapy alone is not better than other interventions, but it is a good complement, especially when adapting the treatment to the psychological characteristics of the patient. ${ }^{149-151}$

\section{Education and self-management strategies}

Education and self-management are useful strategies to include in the management of patients with TMD. When comparing these interventions with occlusal splints, a slight benefit was obtained with education. ${ }^{152}$ However, when compared with other interventions, such as manual therapy or therapeutic exercise, no additional benefits were observed. ${ }^{115,116,152,153}$ Nevertheless, it is assumed that education and self-management strategies are good to combine with other techniques, as observed by Wright et al ${ }^{154}$ and Michelotti et al. ${ }^{152}$ Most studies performed with education and self-management have included only patients with myofascial
TMD, leading to a lack of evidence regarding other types of TMD. There is a need to define better what should be included in patients' education and which self-management strategies are best according to the various types of TMD and regarding the psychosocial impairments that frequently affect patients with TMD. However, the authors consider that public and patient education could be much promising in patients with TMD, especially those based on neuroscience education, because this approach has been shown to reduce pain, disability, and psychological factors in chronic musculoskeletal disorders. ${ }^{154}$

\section{Relaxation techniques}

Relaxation therapy involves self-regulation techniques aimed at reducing pain-induced stress and muscle tension. Relaxation interventions include such techniques as Jacobson's relaxation. These techniques can be reinforced by external feedback using electromyography and/or biofeedback systems for training. Relaxation interventions included in a multimodal treatment could have a positive influence on pain intensity and maximal mouth opening, but there is scarce and controversial evidence. ${ }^{148,155}$

\section{From a biomedical to a biobehavioral approach}

The biomedical model has been an approach used widely in research on the etiological factors involved in TMD. This model has been based on functional theories and structural or morphological-pathological theories that attempt to explain TMD through theoretical concepts on dysfunctions of the condyle-disk complex, traumas, degenerative processes, occlusal concepts, and alterations related to masticatory muscles. ${ }^{21}$ Some theories on the structural and functional biomedical model related to TMD have been useful and some concepts are still valid today, because they consistently explain the disorder from a dysfunctional point of view.

Diagnostic criteria for the classification of TMD based on physical signs and symptoms have had great impact in clinical practice and research, and have provided a standardized means of classification into various subtypes. It is important to highlight that instruments for the classification and evaluation of the psychological components involved in TMD have been included (emotional and cognitive factors), ${ }^{26}$ however, analysis of the research on TMD reveals most studies that classification related to emotional and cognitive factors intended to define the psychological state and disability 
associated with patients' pain has not had much impact on its use for the inclusion criteria or classification of patients.

The basis of the biomedical model is limited when we want to understand in depth the pathophysiology and perpetuation factors related to chronic pain in patients with TMD. A broader view on chronic pain is provided by neuroscientific studies from the last decade. There is strong evidence to suggest that neuroplastic changes and hyperexcitation of the central nervous system (CNS) would be part of those responsible for the central sensitization phenomenon. ${ }^{156}$ Findings present in patients with TMD with chronic pain, such as generalized mechanical hyperalgesia, ${ }^{157}$ structural and functional changes at the brain level, ${ }^{14}$ alteration in pain modulation, comorbidities with other chronic diseases, increased expansion of pain areas, and presence of associated psychological factors would indicate a clinical profile compatible with a central sensitization process. ${ }^{156,158}$ It is important to mention that cognitive aspects, such as memory and learning, are heavily involved in the encoding of affective/emotional aversive stimuli that feed and perpetuate the sensitization process at the central level. ${ }^{159}$

Current literature suggests that psychological and psychosocial factors have an important association with the duration of symptoms and their perpetuation in cases of chronic pain. ${ }^{158,160,161}$ Psychological factors, such as pain catastrophizing, ${ }^{162,163}$ psychological distress, ${ }^{161,164}$ fearavoidance beliefs, ${ }^{165,166}$ beliefs related to painful perception, ${ }^{167}$ depressed or anxious mood, ${ }^{168-170}$ self-efficacy, ${ }^{171}$ and passive coping, ${ }^{164,172-174}$ are related to increased pain perception, increased levels of disability, and movement disorders in patients with chronic painful TMD. On the other hand, it has been noted that some psychosocial factors have also been identified as predictors of treatment outcome in patients with TMD. ${ }^{175}$ We consider that somatic awareness is an important sensory-discriminative factor to be taken into account, since it has been related to an increased risk of suffering a TMD. ${ }^{173,176}$

The abundant current scientific evidence shows that the mechanistic biomedical model is not sufficient to establish a diagnosis or accurate treatment to manage patients with chronic painful TMD. A change in approach toward a more comprehensive and integral vision is necessary. We propose a diagnostic and therapeutic approach based on a biobehavioral approach. Many authors share this thought, ${ }^{177-179}$ even suggesting that from an ethical point of view a compulsory change is needed, given the application of unnecessary and irreversible interventions due to traditional management could endanger the patient's well-being. ${ }^{177,178}$
The biobehavioral model for the diagnosis and treatment of patients with chronic painful TMD recognizes the importance of psychological factors, such as pain history, current emotional and cognitive status, beliefs, learned behaviors, and coping skills, in interaction with the physiological alterations that determine the pain experience. From the therapeutic point of view, the model allows the patients to acquire the ability to self-manage the pain, allowing an improvement in general functioning. ${ }^{180}$

Based on the current clinical and scientific context, we propose a diagnostic and intervention model to address patients with painful TMD based on four dimensions (affective-motivational, sensory-discriminative, cognitiveevaluative, and motor behavior) integrated in a biobehavioral approach (Figure 1). This model has been termed the biobehavioral model of pain perception and motor behavior, and although we have designed it to study any musculoskeletal disorder, in this article we adapt it to TMD. Table 1 presents information about all of these approaches, grade of evidence, and magnitude of effects.

\section{Biobehavioral model of pain perception and motor behavior}

A fundamental aspect of our model is the fact that musculoskeletal pain produces changes in motor behavior. ${ }^{181}$ It has also been observed that pain-related movement disorders are an important cause that influences the impairment of functional capacity and the patient's quality of life, ${ }^{182}$ including the possible interaction that cognitive and emotional aspects can have on the relationship between motor behavior and pain perception. Herein, we briefly describe the theoretical aspects that underlie the biobehavioral model of pain perception and musculoskeletal pain.

Motor changes can be explained through the peripheral and central mechanisms related to the CNS. ${ }^{183,184}$ Experimental studies have found that muscular pain influences motor-control strategies through central mechanisms. ${ }^{185,186}$ On the other hand, several studies have found functional and structural changes in motor cortical areas of patients with chronic pain. ${ }^{187,188}$ In this respect, activation of the supplementary motor area in patients with TMD when faced with adverse cognitive or emotional stimuli has been observed. ${ }^{189}$ That same activation has been found in patients with TMD who have catastrophic helplessness. ${ }^{190}$ It is important to mention that the supplementary motor area plays an important role in movement planning, and it is theorized that the preactivation of this area found in cases of chronic pain could 


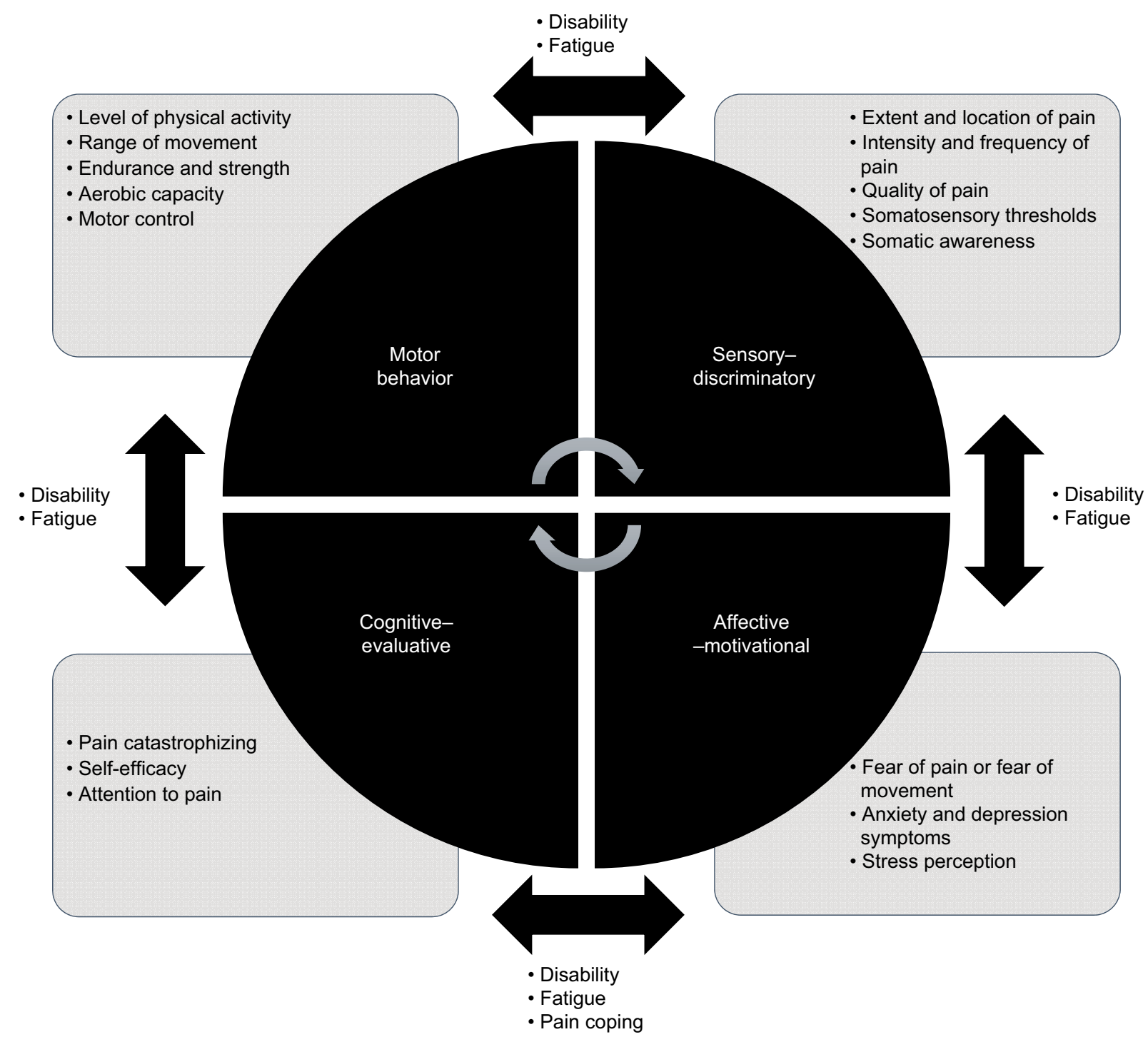

Figure I The four dimensions of the biobehavioral model of pain perception and motor behavior.

Notes: The four circle segments are variables for assessment and treatment according to each dimension. Outside boxes are transverse or aspecific variables that are dependent on interactions among the different dimensions.

be due to the preparation of avoidance or anticipatory motor behaviors. We have scientific evidence revealing neurophysiological mechanisms of motor anticipation related to pain perception. ${ }^{191,192}$ Pain-protection behaviors can include motor activities, such as avoidance of movement and tendencies to touch the affected area of the body. ${ }^{193}$ It has been proposed that the motor responses involved in the pain experience can be activated when the intensity of the pain rises beyond a certain threshold. ${ }^{194}$

Emotional factors related to fear of pain play an important role in the degree of protective behaviors triggered by pain. ${ }^{195}$ Recent research has shown that high levels of fear of pain are associated with being less physically active, ${ }^{196,197}$ limited range of motion, ${ }^{198,199}$ physical disability, ${ }^{200}$ and strategies for adopting alternative movements. ${ }^{201}$ It should be noted that behaviors associated with psychological distress, interruption of activity, and avoidance of activity are essential components in pain-related disability. ${ }^{202}$

Motor behavior related to painful experiences can vary according to the case. Some patients with chronic pain use passive motor strategies to avoid pain; however, other patients use active self-regulation strategies to cope with pain. ${ }^{203}$ Simmonds et al reported that movement dysfunction was not only a consequence of anticipating and minimizing pain. The motor component involved is an even more complicated problem that involves social, environmental, 
Table I Evidence on treatment options for pain related to TMD

\begin{tabular}{|c|c|c|c|}
\hline $\begin{array}{l}\text { Treatment } / \\
\text { intervention }\end{array}$ & Evidence-based & Type of TMD & Magnitude of effects \\
\hline $\begin{array}{l}\text { Oral and topical } \\
\text { pharmacotherapy }\end{array}$ & $\begin{array}{l}\text { One meta-analysis, }{ }^{61} \text { two } \\
\text { RCTs s } \\
\text { One meta-analysis, }{ }^{61} \text { one } \\
\text { RCT }{ }^{73} \text { one } C^{75}\end{array}$ & $\begin{array}{l}\text { Arthrogenic } \\
\text { Myogenic }\end{array}$ & $\begin{array}{l}\text { Joint-pain reduction achieved with oral sodium diclofenac, } \\
\text { naproxen sodium, and topical diclofenac } \\
\text { Muscle-pain reduction obtained with diazepam; cyclobenzaprine } \\
\text { for local spasm and acute muscle pain; sodium diclofenac with } \\
\text { coadjuvants (acetaminophen, carisoprodol, caffeine) for muscle } \\
\text { pain; amitriptyline and nortriptyline used for masticatory } \\
\text { myofascial chronic pain }\end{array}$ \\
\hline $\begin{array}{l}\text { Infiltrated } \\
\text { pharmacotherapy }\end{array}$ & One meta-analysis $^{61}$ & Arthrogenic & $\begin{array}{l}\text { Injection with corticosteroid } \beta \text {-metasone and hyaluronate for joint } \\
\text { pain }\end{array}$ \\
\hline $\begin{array}{l}\text { Dental management: } \\
\text { occlusal splints } \\
\text { Physical therapy }\end{array}$ & One systematic review ${ }^{98}$ & Myogenic & $\begin{array}{l}\text { Stabilization splints can be used to prevent dental damage in } \\
\text { patients with bruxism }\end{array}$ \\
\hline \multirow[t]{3}{*}{ - Manual therapy } & $\begin{array}{l}\text { One meta-analysis, }{ }^{52} \text { one } \\
\text { systematic review }\end{array}$ & Myogenic & $\begin{array}{l}\text { Intra- and extraoral myofascial techniques are effective in reducing } \\
\text { pain and increasing mouth opening }\end{array}$ \\
\hline & One meta-analysis ${ }^{52}$ & Myogenic and mixed & $\begin{array}{l}\text { Manual therapy (joint and myofascial approach) on the jaw } \\
\text { and cervical regions produces similar effects to other usual } \\
\text { conservative treatments (splints, exercise, and/or toxins) to } \\
\text { improve pain and mandibular function }\end{array}$ \\
\hline & $\begin{array}{l}\text { One meta-analysis, }{ }^{52} \text { one } \\
\text { systematic review }\end{array}$ & Myogenic & $\begin{array}{l}\text { Upper cervical joint mobilizations are effective in reducing pain } \\
\text { intensity }\end{array}$ \\
\hline \multirow[t]{3}{*}{ - Therapeutic exercise } & $\begin{array}{l}\text { One meta-analysis, }{ }^{52} \text { two } \\
\text { systematic reviews }{ }^{45,46}\end{array}$ & Myogenic & $\begin{array}{l}\text { Postural exercise combined with self-management care and/ } \\
\text { or cognitive-behavior treatment is more effective than self- } \\
\text { management alone in decreasing pain symptomatology and } \\
\text { increasing mouth opening }\end{array}$ \\
\hline & One meta-analysis ${ }^{52}$ & $\begin{array}{l}\text { Myogenic, articular, } \\
\text { mixed }\end{array}$ & $\begin{array}{l}\text { A general exercise program focused on the jaw and/or cervical } \\
\text { region is effective for reducing pain intensity and improving } \\
\text { mandibular function, but not more effective than other } \\
\text { interventions }\end{array}$ \\
\hline & One meta-analysis ${ }^{52}$ & Myogenic & $\begin{array}{l}\text { A general exercise program is more effective than splint devices to } \\
\text { increase ROM in mouth opening }\end{array}$ \\
\hline \multirow[t]{2}{*}{$\begin{array}{l}\text { - Manual therapy and } \\
\text { therapeutic exercise }\end{array}$} & $\begin{array}{l}\text { One meta-analysis, }{ }^{52} \text { two } \\
\text { systematic reviews }{ }^{45,46}\end{array}$ & Articular and mixed & $\begin{array}{l}\text { Manual therapy plus therapeutic exercise is more effective than } \\
\text { other active interventions for improving pain and jaw ROM }\end{array}$ \\
\hline & One meta-analysis ${ }^{52}$ & Mixed & $\begin{array}{l}\text { Manual therapy plus therapeutic exercise applied to the orofacial } \\
\text { and cervical region could be more effective than application on } \\
\text { cervical region alone for improving mouth opening }\end{array}$ \\
\hline \multirow[t]{4}{*}{$\begin{array}{l}\text { - Dry needling and } \\
\text { acupuncture }\end{array}$} & $\begin{array}{l}\text { Three meta-analyses, }{ }^{132,133,142} \\
\text { one systematic review }\end{array}$ & Myogenic & $\begin{array}{l}\text { Acupuncture is effective in decreasing pain intensity, but not to } \\
\text { increase mouth-opening ROM }\end{array}$ \\
\hline & $\begin{array}{l}\text { One meta-analysis, }{ }^{142} \text { one } \\
\text { systematic review }{ }^{141}\end{array}$ & Myogenic & $\begin{array}{l}\text { Acupuncture could be more effective when applied to the } \\
\text { orofacial region than remote regions, and not necessarily at } \\
\text { standard acupuncture points }\end{array}$ \\
\hline & Two meta-analyses ${ }^{132,133}$ & Myogenic & $\begin{array}{l}\text { Acupuncture produces greater pain decrease than sham } \\
\text { nonpenetrating acupuncture, but not sham penetrating } \\
\text { acupuncture }\end{array}$ \\
\hline & Three RCTs $s^{126,128,145}$ & Myogenic & $\begin{array}{l}\text { Dry needling may be effective for pain-intensity reduction and } \\
\text { increasing mouth opening }\end{array}$ \\
\hline - Electrotherapy & One meta-analysis ${ }^{146}$ & Articular and mixed & Low-level laser therapy is effective in improving jaw ROM \\
\hline Surgical interventions & Three meta-analyses ${ }^{81-83}$ & Arthrogenic & $\begin{array}{l}\text { Internal derangements are better managed with nonsurgical } \\
\text { interventions }\end{array}$ \\
\hline $\begin{array}{l}\text { Cognitive-behavioral } \\
\text { therapy }\end{array}$ & One meta-analysis ${ }^{151}$ & Myogenic and mixed & $\begin{array}{l}\text { Good complement for disability and pain reduction in patients } \\
\text { with specific psychological characteristics }\end{array}$ \\
\hline $\begin{array}{l}\text { Education and self- } \\
\text { management }\end{array}$ & Two meta-analyses ${ }^{151,218}$ & Myogenic and mixed & $\begin{array}{l}\text { Good complements to combine with other techniques, since } \\
\text { they are low-cost interventions and potentially control signs and } \\
\text { symptoms }\end{array}$ \\
\hline Relaxation techniques & One meta-analysis ${ }^{155}$ & Myogenic & $\begin{array}{l}\text { May be beneficial in reducing maximal pain and active mouth } \\
\text { opening }\end{array}$ \\
\hline
\end{tabular}

Abbreviations: RCT, randomized controlled trial; ROM, range of motion. 
and psychological factors (cognitions and emotions) that can influence motor activity as a complex multidimensional construct. ${ }^{204}$ Several motor programs have been proposed for the various forms of pain behavior. These can be organized at various levels of the CNS, and can be influenced by social and psychological factors. ${ }^{195}$

Current evidence holds that in addition to fear of pain, other psychosocial factors might contribute to generating pain-related functional alterations. ${ }^{205-207}$ In this regard, Sullivan suggested that certain psychological factors, such as pain catastrophizing, fear, and depression can influence pain by reducing the threshold of activation of motor programs related to pain perception. ${ }^{195}$

In summary, the biobehavioral model of pain perception and motor behavior presents a specific framework to help us understand the mechanisms involved in chronic painful TMD. Basically, we propose that sustained pain perception produces neuroplastic changes in the CNS that have implications for motor behavior that are directly and indirectly influenced by cognitive and emotional factors. In this model, the motor behavior is an essential element, given its alteration would increase levels of disability, leading to poorer quality of life, and would increase the perception of pain intensity.

Poor motor behavior can be influenced by fear-avoidance beliefs, a decrease in self-efficacy expectations, catastrophic cognition, and an increase in depressive symptoms. Furthermore, pain-related movement disorders are a means of learning maladaptation that increases the attention to and memory of pain, favoring the perpetuation of the painful experience (Figure 2). Behavioral changes associated with the experience of the perception of maintained pain can cause various movement dysfunctions, mainly when a passive coping strategy is used. The result of this situation is an increase in disability levels (Figure 2).

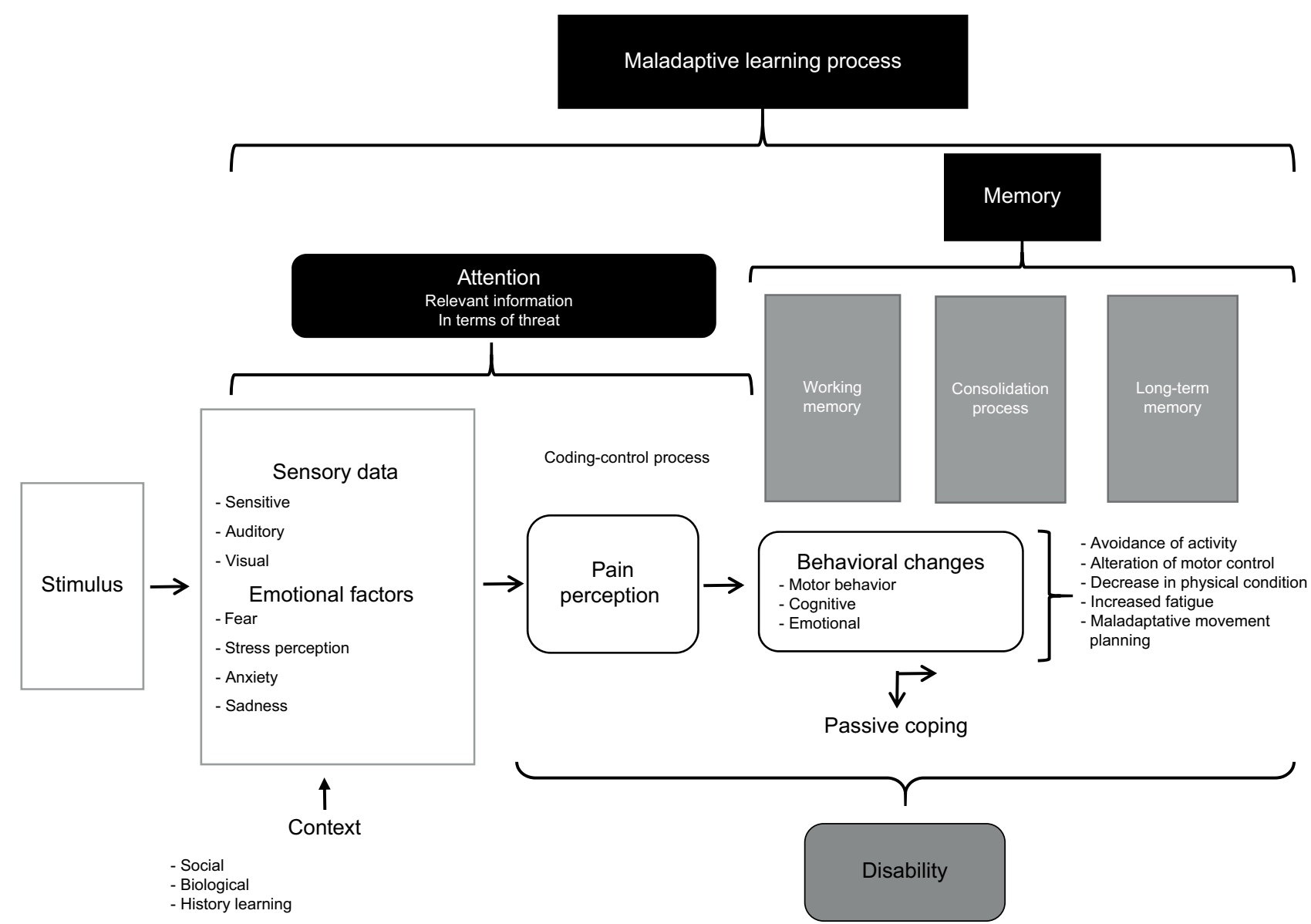

Figure 2 Mechanisms involved in the biobehavioral model of pain perception and motor behavior.

Notes: Generation of pain perception from somatosensory or emotional stimuli or the combination of both according to different contexts can influence increased or decreased pain perception. The black boxes show the cognitive processes involved in the maintenance and "chronification" of symptoms from behavioral changes, emphasizing those related to motor behavior that in turn can influence feedback and learning for the maintenance of pain perception and increase perceived disability. 
To perform adequate clinical reasoning and undertake a good diagnostic approach using this model, it is necessary to evaluate the four dimensions and try to discern how they interact with one another, and especially to evaluate what factors are relevant (Figure 1). We recommend performing an assessment that objectifies sensorimotor variables through physical tests and an evaluation of cognitive and emotional factors using self-reports to quantify them. In Figure 1, we suggest the variables that should be evaluated to work with the biobehavioral model of pain perception and motor behavior.

The therapeutic approach we suggest attempts to provide a comprehensive framework for the treatment of patients with chronic painful TMD. The main variable to achieve optimum functional recovery is disability: we propose that if we improve the motor behavior, we will decrease the disability and in turn the painful perception. Therefore, we consider the possibility of a bidirectional relationship through which the treatment that reduces the painful perception can also favor the recovery of motor behavior while decreasing the disability. In order to achieve this change, it is necessary to eliminate erroneous beliefs and negative cognitions that could alter the treatment results. It will also be necessary to use motivational strategies that promote good adherence and compliance with the various types of treatments. It is important to mention that the treatment proposed herein has as a central therapeutic axis the movement to reduce pain and improve function. In relation to this, Luomajoki et al found that treatment with therapeutic exercise to improve motor performance also resulted in an improvement in pain and disability in patients with low-back pain. ${ }^{208}$ In our model, we also integrate therapeutic strategies, such as therapeutic exercise, that can specifically reduce pain and would make treatment more effective.

Current scientific evidence shows the ability of therapeutic exercise to modulate pain in experimental conditions. ${ }^{209-211}$ In addition, we have strong scientific clinically relevant evidence that demonstrates the effectiveness of therapeutic exercise in reducing disability and pain intensity in other chronic musculoskeletal conditions. ${ }^{212-217}$

\section{Multimodal treatment based on a biobehavioral approach}

The treatment we propose has a multimodal point of view, but could also be structured in a multidisciplinary way, including the therapeutic interventions of physiotherapists, dentists, psychologists, and physicians. Based on current scientific evidence, we can say that a conservative approach appears to be the best option for the management of chronic painful TMD.

The treatment methods included in the therapeutic approach of this model are structured to achieve three objectives: reduction in pain perception, improvement of motor behavior, and improvement of cognitive and emotional factors related to the experience of pain. To reduce pain intensity, we propose the use of manual therapy, DN, and pharmacology. For improvements in pain and mandibular function, it is relevant to apply a combined intervention of manual therapy and therapeutic exercise directed to the orofacial, craniomandibular, and upper cervical regions. Although it is not yet a sufficiently investigated aspect, we consider that the prescription of generalized exercise in both aerobic and anaerobic modalities could be beneficial for patients with chronic conditions, which could favor the activation of the descending inhibitory system of pain, improve physical condition, and decrease the attentional focus on pain perception. In addition, splints appear to play a prominent role in the protection of dentition.

In order to improve the effectiveness of the aforementioned treatments, it is necessary to apply them in combination with biobehavioral treatments and strategies, in which we would emphasize therapeutic education, cognitive behavioral therapy, experiential motor restructuring, graded exposure to activity, sensory reinterpretation and retraining, counseling, and methods of physiological self-regulation, such as training in relaxation and biofeedback. These treatments should aim to improve adherence to therapeutic exercise and self-management techniques, eradicate counterproductive habits, encourage positive behaviors, reduce catastrophic cognition, reconceptualize erroneous beliefs about pain and movement, reduce fear-avoidance behaviors, improve stress management, and improve the patients' knowledge of therapeutic exercise benefits. In Figure 3, we present relevant aspects and recommendations to be taken into account for the approach and development of treatment from the biobehavioral model of pain perception and motor behavior. It is also important to mention that the treatment that we propose is applicable to patients with chronic painful TMD. For cases of acute or subacute pain, it is possible that less complex unimodal or bimodal approaches would have good effectiveness.

\section{Disclosure}

The authors report no conflicts of interest in this work. 


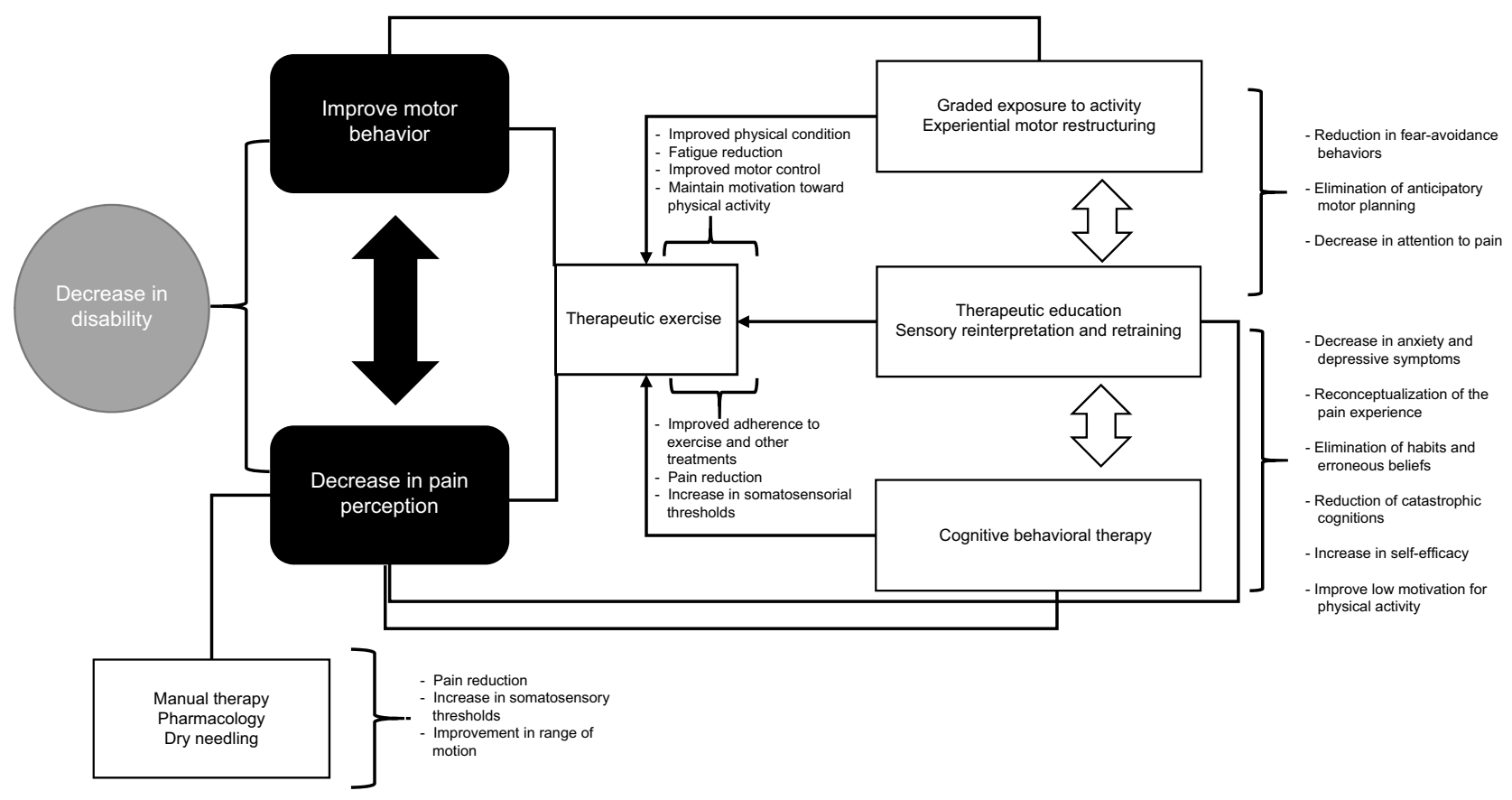

Figure 3 Representation of the therapeutic approach according to the biobehavioral model of pain perception and motor behavior.

Notes: An essential objective within the model is the reduction of the disability. It is proposed that this objective can be approached from the achievement of two secondary objectives: reduction in perception of pain, and improvement in motor behavior. It is a biobehavioral therapeutic structure based on diverse treatment methods that influence the four dimensions raised in the model.

\section{References}

1. Ibsen OA, Phelan JA. Oral Pathology for the Dental Hygienist. 6th ed. Saint Louis: Saunders; 2013.

2. Conti PC, Pinto-Fiamengui LM, Cunha CO, Conti AC. Orofacial pain and temporomandibular disorders: the impact on oral health and quality of life. Braz Oral Res. 2012;26 (Suppl 1):120-123.

3. Zakrzewska JM. Temporomandibular disorders, headaches and chronic pain. J Pain Palliat Care Pharmacother. 2015;29(1):61-63.

4. Magnusson T, Egermark I, Carlsson GE. A longitudinal epidemiologic study of signs and symptoms of temporomandibular disorders from 15 to 35 years of age. J Orofac Pain. 2000;14(4):310-319.

5. Giannakopoulos NN, Keller L, Rammelsberg P, Kronmüller KT, Schmitter M. Anxiety and depression in patients with chronic temporomandibular pain and in controls. J Dent. 2010;38(5):369-376.

6. Reiter S, Emodi-Perlman A, Goldsmith C, Friedman-Rubin P, Winocur E. Comorbidity between depression and anxiety in patients with temporomandibular disorders according to the research diagnostic criteria for temporomandibular disorders. J Oral Facial Pain Headache. 2015;29(2):135-143.

7. Gil-Martínez A, Grande-Alonso M, La Touche R, Lara-Lara M, LópezLópez A, Fernández-Carnero J. Psychosocial and somatosensory factors in women with chronic migraine and painful temporomandibular disorders. Pain Res Manag. 2016;2016:3945673.

8. Greene CS. Orthodontics and temporomandibular disorders. Dent Clin North Am. 1988;32(3):529-538.

9. Bales JM, Epstein JB. The role of malocclusion and orthodontics in temporomandibular disorders. J Can Dent Assoc. 1994;60(10):899-905.

10. McNamara JA, Türp JC. Orthodontic treatment and temporomandibular disorders: is there a relationship? Part 1: clinical studies. J Orofac Orthop. 1997;58(2):74-89.

11. Guo C, Shi Z, Revington P. Arthrocentesis and lavage for treating temporomandibular joint disorders. Cochrane Database Syst Rev. 2009;(4):CD004973.

12. Orlando B, Manfredini D, Salvetti G, Bosco M. Evaluation of the effectiveness of biobehavioral therapy in the treatment of temporomandibular disorders: a literature review. Behav Med. 2007;33(3):101-118.
13. Stowell AW, Gatchel RJ, Wildenstein L. Cost-effectiveness of treatments for temporomandibular disorders: biopsychosocial intervention versus treatment as usual. J Am Dent Assoc. 2007;138(2):202-208.

14. Lin CS. Brain signature of chronic orofacial pain: a systematic review and meta-analysis on neuroimaging research of trigeminal neuropathic pain and temporomandibular joint disorders. PLoS One. 2014;9(4):e94300.

15. Oono Y, Wang K, Baad-Hansen L, et al. Conditioned pain modulation in temporomandibular disorders (TMD) pain patients. Exp Brain Res. 2014;232(10):3111-3119.

16. Suvinen TI, Kemppainen P, Le Bell Y, Valjakka A, Vahlberg T, Forssell $\mathrm{H}$. Research diagnostic criteria Axis II in screening and as a part of biopsychosocial subtyping of Finnish patients with temporomandibular disorder pain. J Orofac Pain. 2013;27(4):314-324.

17. Ghurye S, McMillan R. Pain-related temporomandibular disorder: current perspectives and evidence-based management. Dent Update. 2015;42(6):533-536, 539-542, 545-546.

18. Epker J, Gatchel RJ. Coping profile differences in the biopsychosocial functioning of patients with temporomandibular disorder. Psychosom Med. 2000;62(1):69-75.

19. LeResche L. Epidemiology of temporomandibular disorders: implications for the investigation of etiologic factors. Crit Rev Oral Biol Med. 1997;8(3):291-305.

20. Sena MF, Mesquita KS, Santos FR, Silva FW, Serrano KV. Prevalence of temporomandibular dysfunction in children and adolescents. Rev Paul Pediatr. 2013;31(4):538-545.

21. Suvinen TI, Reade PC, Kemppainen P, Könönen M, Dworkin SF. Review of aetiological concepts of temporomandibular pain disorders: towards a biopsychosocial model for integration of physical disorder factors with psychological and psychosocial illness impact factors. Eur J Pain. 2005;9(6):613-633.

22. Graff-Radford SB. Temporomandibular disorders and headache. Dent Clin North Am. 2007;51(1):129-144.

23. John MT, Hirsch C, Reiber T, Dworkin SF. Translating the research diagnostic criteria for temporomandibular disorders into German: evaluation of content and process. J Orofac Pain. 2006;20(1):43-52. 
24. Khoo SP, Yap AU, Chan YH, Bulgiba AM. Translating the research diagnostic criteria for temporomandibular disorders into Malay: evaluation of content and process. J Orofac Pain. 2008;22(2):131-138.

25. John MT, Dworkin SF, Mancl LA. Reliability of clinical temporomandibular disorder diagnoses. Pain. 2005;118(1-2):61-69.

26. Schiffman, Ohrbach R, Truelove E, et al. Diagnostic criteria for temporomandibular disorders (DC/TMD) for clinical and research applications: recommendations of the International RDC/TMD Consortium Network and Orofacial Pain Special Interest Group. J Oral Facial Pain Headache. 2014;28(1):6-27.

27. Kaji A, Maeda T, Watanabe S. Parasympathetic innervation of cutaneous blood vessels examined by retrograde tracing in the rat lower lip. J Auton Nerv Syst. 1991;32(2):153-158.

28. Sanders RD. The trigeminal (V) and facial (VII) cranial nerves: head and face sensation and movement. Psychiatry (Edgmont). 2010;7(1):13-16.

29. Bathla G, Hegde AN. The trigeminal nerve: an illustrated review of its imaging anatomy and pathology. Clin Radiol. 2013;68(2):203-213.

30. Young RF, King RB. Fiber spectrum of the trigeminal sensory root of the baboon determined by electron microscopy. J Neurosurg. 1973;38(1):65-72.

31. Pellegrini JJ, Horn AK, Evinger C. The trigeminally evoked blink reflex - I: neuronal circuits. Exp Brain Res. 1995;107(2):166-180.

32. Hoffmann KD, Matthews MA. Comparison of sympathetic neurons in orofacial and upper extremity nerves: implications for causalgia. J Oral Maxillofac Surg. 1990;48(7):720-727.

33. Uddman R, Tajti J, Möller S, Sundler F, Edvinsson L. Neuronal messengers and peptide receptors in the human sphenopalatine and otic ganglia. Brain Res. 1999;826(2):193-199.

34. Takemura M, Sugiyo S, Moritani M, Kobayashi M, Yonehara N. Mechanisms of orofacial pain control in the central nervous system. Arch Histol Cytol. 2006;69(2):79-100.

35. Sessle BJ. Peripheral and central mechanisms of orofacial pain and their clinical correlates. Minerva Anestesiol. 2005;71(4):117-136.

36. Sessle BJ. Neural mechanisms and pathways in craniofacial pain. Can J Neurol Sci. 1999;26 (Suppl 3):S7-S11.

37. Sessle BJ. Acute and chronic craniofacial pain: brainstem mechanisms of nociceptive transmission and neuroplasticity, and their clinical correlates. Crit Rev Oral Biol Med. 2000;11(1):57-91.

38. Sessle BJ. Peripheral and central mechanisms of orofacial inflammatory pain. Int Rev Neurobiol. 2011;97:179-206.

39. Burstein R, Yamamura H, Malick A, Strassman AM. Chemical stimulation of the intracranial dura induces enhanced responses to facial stimulation in brain stem trigeminal neurons. J Neurophysiol. 1998;79(2):964-982.

40. Gauer RL, Semidey MJ. Diagnosis and treatment of temporomandibular disorders. Am Fam Physician. 2015;91(6):378-386.

41. Dworkin SF, Huggins KH, LeResche L, et al. Epidemiology of signs and symptoms in temporomandibular disorders: clinical signs in cases and controls. J Am Dent Assoc. 1990;120(3):273-281.

42. Oral K, Bal Küçük B, Ebeoğlu B, Dinçer S. Etiology of temporomandibular disorder pain. Agri. 2009;21(3):89-94.

43. Fricton JR, Ouyang W, Nixdorf DR, Schiffman EL, Velly AM, Look JO. Critical appraisal of methods used in randomized controlled trials of treatments for temporomandibular disorders. J Orofac Pain. 2010;24(2):139-151.

44. Ingawalé $\mathrm{S}$, Goswami $\mathrm{T}$. Temporomandibular joint: disorders, treatments, and biomechanics. Ann Biomed Eng. 2009;37(5):976-996.

45. McNeely ML, Olivo SA, Magee DJ. A systematic review of the effectiveness of physical therapy interventions for temporomandibular disorders. Phys Ther. 2006;86(5):710-725.

46. Medlicott MS, Harris SR. A systematic review of the effectiveness of exercise, manual therapy, electrotherapy, relaxation training, and biofeedback in the management of temporomandibular disorder. Phys Ther. 2006;86(7):955-973.
47. Paço M, Peleteiro B, Duarte J, Pinho T. The effectiveness of physiotherapy in the management of temporomandibular disorders: a systematic review and meta-analysis. J Oral Facial Pain Headache. 2016;30(3):210-220.

48. Scrivani SJ, Keith DA, Kaban LB. Temporomandibular disorders. N Engl J Med. 2008;359(25):2693-2705.

49. List T, Axelsson S. Management of TMD: evidence from systematic reviews and meta-analyses. J Oral Rehabil. 2010;37(6):430-451.

50. Syrop SB. Initial management of temporomandibular disorders. Dent Today. 2002;21(8):52-57.

51. Dimitroulis G, Gremillion HA, Dolwick MF, Walter JH. Temporomandibular disorders - 2: non-surgical treatment. Aust Dent J. 1995;40(6):372-376.

52. Armijo-Olivo S, Pitance L, Singh V, Neto F, Thie N, Michelotti A. Effectiveness of manual therapy and therapeutic exercise for temporomandibular disorders: systematic review and meta-analysis. Phys Ther. 2016;96(1):9-25.

53. List T, Axelsson S. Management of TMD: evidence from systematic reviews and meta-analyses. J Oral Rehabil. 2010;37(6):430-451.

54. Dıraçoğlu D, Saral İB, Keklik B, et al. Arthrocentesis versus nonsurgical methods in the treatment of temporomandibular disc displacement without reduction. Oral Surg Oral Med Oral Pathol Oral Radiol Endod. 2009;108(1):3-8.

55. Stegenga B, de Bont LG, Dijkstra PU, Boering G. Short-term outcome of arthroscopic surgery of temporomandibular joint osteoarthrosis and internal derangement: a randomized controlled clinical trial. Br J Oral Maxillofac Surg. 1993;31(1):3-14.

56. Mujakperuo HR, Watson M, Morrison R, Macfarlane TV. Pharmacological interventions for pain in patients with temporomandibular disorders. Cochrane Database Syst Rev. 2010;(10):CD004715.

57. Agius AM, Jones NS, Muscat R. A randomized controlled trial comparing the efficacy of low-dose amitriptyline, amitriptyline with pindolol and surrogate placebo in the treatment of chronic tension-type facial pain. Rhinology. 2013;51(2):143-153.

58. White AP, Arnold PM, Norvell DC, Ecker E, Fehlings MG. Pharmacologic management of chronic low back pain. Spine (Phila Pa 1976). 2011;36(21 Suppl):S131-S143.

59. Gewandter JS, McDermott MP, McKeown A, et al. Reporting of crossover clinical trials of analgesic treatments for chronic pain: Analgesic, Anesthetic, and Addiction Clinical Trial Translations, Innovations, Opportunities, and Networks systematic review and recommendations. Pain. 2016;157(11):2544-2551.

60. Firmani M, Miralles R, Casassus R. Effect of lidocaine patches on upper trapezius EMG activity and pain intensity in patients with myofascial trigger points: a randomized clinical study. Acta Odontol Scand. 2015;73(3):210-218.

61. Häggman-Henrikson B, Alstergren P, Davidson T, et al. Pharmacological treatment of orofacial pain: health technology assessment including a systematic review with network meta-analysis. $J$ Oral Rehabil. 2017;44(10):800-826.

62. Ta LE, Dionne RA. Treatment of painful temporomandibular joints with a cyclooxygenase-2 inhibitor: a randomized placebo-controlled comparison of celecoxib to naproxen. Pain. 2004;111(1-2):13-21.

63. de Carli ML, Guerra MB, Nunes TB, et al. Piroxicam and laser phototherapy in the treatment of TMJ arthralgia: a double-blind randomised controlled trial. J Oral Rehabil. 2013;40(3):171-178.

64. Gabrielsson L, Mattsson S, Fowler CJ. Palmitoylethanolamide for the treatment of pain: pharmacokinetics, safety and efficacy. $\mathrm{Br} J$ Clin Pharmacol. 2016;82(4):932-942.

65. Marini I, Bartolucci ML, Bortolotti F, Gatto MR, Bonetti GA. Palmitoylethanolamide versus a nonsteroidal anti-inflammatory drug in the treatment of temporomandibular joint inflammatory pain. J Orofac Pain. 2012;26(2):99-104.

66. Gabrielsson L, Gouveia-Figueira S, Häggström J, Alhouayek M, Fowler CJ. The anti-inflammatory compound palmitoylethanolamide inhibits prostaglandin and hydroxyeicosatetraenoic acid production by a macrophage cell line. Pharmacol Res Perspect. 2017;5(2): e 00300 . 
67. Businco LR, Businco AR, D’Emilia M, Lauriello M, Tirelli GC. Topical versus systemic diclofenac in the treatment of temporomandibular joint dysfunction symptoms. Acta Otorhinolaryngol Ital. 2004;24(5):279-283.

68. Dong XD, Svensson P, Cairns BE. The analgesic action of topical diclofenac may be mediated through peripheral NMDA receptor antagonism. Pain. 2009;147(1-3):36-45.

69. Cairns BE. Pathophysiology of TMD pain: basic mechanisms and their implications for pharmacotherapy. J Oral Rehabil. 2010;37(6):391-410.

70. Singer E, Dionne R. A controlled evaluation of ibuprofen and diazepam for chronic orofacial muscle pain. J Orofac Pain. 1997;11(2):139-46.

71. Pramod G, Shashikanth M, Shambulingappa P, Lele S. Analgesic efficacy of diazepam and placebo in patients with temporomandibular disorders: a double blind randomized clinical trial. Indian J Dent Res. 2011;22(3):404-409.

72. Herman CR, Schiffman EL, Look JO, Rindal DB. The effectiveness of adding pharmacologic treatment with clonazepam or cyclobenzaprine to patient education and self-care for the treatment of jaw pain upon awakening: a randomized clinical trial. J Orofac Pain. 2002;16(1):64-70.

73. Varoli FK, Pita MS, Sato S, Issa JP, do Nascimento C, Pedrazzi V. Analgesia evaluation of 2 NSAID drugs as adjuvant in management of chronic temporomandibular disorders. ScientificWorldJournal. 2015;2015:359152.

74. Plesh O, Adams SH, Gansky SA. Temporomandibular joint and muscle disorder-type pain and comorbid pains in a national US sample. J Orofac Pain. 2011;25(3):190-198.

75. Haviv Y, Rettman A, Aframian D, Sharav Y, Benoliel R. Myofascial pain: an open study on the pharmacotherapeutic response to stepped treatment with tricyclic antidepressants and gabapentin. J Oral Facial Pain Headache. 2015;29(2):144-151.

76. Kimos P, Biggs C, Mah J, et al. Analgesic action of gabapentin on chronic pain in the masticatory muscles: a randomized controlled trial. Pain. 2007;127(1-2):151-160.

77. Li C, Zhang Y, Lv J, Shi Z. Inferior or double joint spaces injection versus superior joint space injection for temporomandibular disorders: a systematic review and meta-analysis. J Oral Maxillofac Surg. 2012;70(1):37-44.

78. Chen YW, Chiu YW, Chen CY, Chuang SK. Botulinum toxin therapy for temporomandibular joint disorders: a systematic review of randomized controlled trials. Int J Oral Maxillofac Surg. 2015;44(8):1018-1026.

79. Ward SR, Minamoto VB, Suzuki KP, Hulst JB, Bremner SN, Lieber $\mathrm{RL}$. Recovery of rat muscle size but not function more than 1 year after a single botulinum toxin injection. Muscle Nerve. Epub 2017 May 26.

80. Kwanchuay P, Petchnumsin T, Yiemsiri P, Pasuk N, Srikanok W, Hathaiareerug C. Efficacy and safety of single botulinum toxin type A (Botox) injection for relief of upper trapezius myofascial trigger point: a randomized, double-blind, placebo-controlled study. $J$ Med Assoc Thai. 2015;98(12):1231-1236.

81. Al-Moraissi EA. Open versus arthroscopic surgery for the management of internal derangement of the temporomandibular joint: a meta-analysis of the literature. Int J Oral Maxillofac Surg. 2015;44(6):763-770.

82. Rigon M, Pereira LM, Bortoluzzi MC, Loguercio AD, Ramos AL, Cardoso JR. Arthroscopy for temporomandibular disorders. Cochrane Database Syst Rev. 2011;(5):CD006385.

83. Bouchard C, Goulet JP, El-Ouazzani M, Turgeon AF. Temporomandibular lavage versus nonsurgical treatments for temporomandibular disorders: a systematic review and meta-analysis. J Oral Maxillofac Surg. 2017;75(7):1352-1362.

84. Vos LM, Huddleston Slater JJ, Stegenga B. Lavage therapy versus nonsurgical therapy for the treatment of arthralgia of the temporomandibular joint: a systematic review of randomized controlled trials. J Orofac Pain. 2013;27(2):171-179.

85. Schiffman EL, Look JO, Hodges JS, et al. Randomized effectiveness study of four therapeutic strategies for TMJ closed lock. J Dent Res. 2007;86(1):58-63.
86. Al-Baghdadi M, Durham J, Araujo-Soares V, Robalino S, Errington L, Steele J. TMJ disc displacement without reduction management. $J$ Dent Res. 2014;93(7 Suppl):37S-51S.

87. Kiliç SC, Güngörmüş M, Sümbüllü MA. Is Arthrocentesis plus platelet-rich plasma superior to arthrocentesis alone in the treatment of temporomandibular joint osteoarthritis? A randomized clinical trial. J Oral Maxillofac Surg. 2015;73(8):1473-1483.

88. Hanc1 M, Karamese M, Tosun Z, Aktan TM, Duman S, Savaci N. Intra-articular platelet-rich plasma injection for the treatment of temporomandibular disorders and a comparison with arthrocentesis. J Craniomaxillofac Surg. 2015;43(1):162-166.

89. Hegab AF, Ali HE, Elmasry M, Khallaf MG. Platelet-rich plasma injection as an effective treatment for temporomandibular joint osteoarthritis. J Oral Maxillofac Surg. 2015;73(9):1706-1713.

90. Varga ML. Orthodontic therapy and temporomandibular disorders. Med Sci. 2010;34:75-85.

91. Koh H, Robinson PG. Occlusal adjustment for treating and preventing temporomandibular joint disorders. J Oral Rehabil. 2004;31(4):287-292.

92. Luther F, Layton S, McDonald F. Orthodontics for treating temporomandibular joint (TMJ) disorders. Cochrane Database Syst Rev. 2010;(7):CD006541.

93. Al-Ani Z, Gray RJ, Davies SJ, Sloan P, Glenny AM. Stabilization splint therapy for the treatment of temporomandibular myofascial pain: a systematic review. J Dent Educ. 2005;69(11):1242-1250.

94. Klasser GD, Greene CS. Oral appliances in the management of temporomandibular disorders. Oral Surg Oral Med Oral Pathol Oral Radiol Endod. 2009;107(2):212-223.

95. Harada T, Ichiki R, Tsukiyama Y, Koyano K. The effect of oral splint devices on sleep bruxism: a 6-week observation with an ambulatory electromyographic recording device. J Oral Rehabil. 2006;33(7):482-488.

96. Nascimento LL, Amorim CF, Giannasi LC, et al. Occlusal splint for sleep bruxism: an electromyographic associated to Helkimo Index evaluation. Sleep Breath. 2008;12(3):275-280.

97. Motamedi MH, Navi F, Pourshahab M, et al. Outcomes of management of early temporomandibular joint disorders: how effective is nonsurgical therapy in the long-term? Natl J Maxillofac Surg. 2010;1(2): 108-111.

98. Macedo CR, Silva AB, Machado MA, Saconato H, Prado GF. Occlusal splints for treating sleep bruxism (tooth grinding). Cochrane Database Syst Rev. 2007;(4):CD005514.

99. Sturdivant J, Fricton JR. Physical therapy for temporomandibular disorders and orofacial pain. Curr Opin Dent. 1991;1(4):485-496.

100. Calixtre LB, Moreira RF, Franchini GH, Alburquerque-Sendín F, Oliveira AB. Manual therapy for the management of pain and limited range of motion in subjects with signs and symptoms of temporomandibular disorder: a systematic review of randomised controlled trials. J Oral Rehabil. 2015;42(11):847-861.

101. Weerapong P, Hume PA, Kolt GS. The mechanisms of massage and effects on performance, muscle recovery and injury prevention. Sports Med. 2005;35(3):235-256.

102. 103. Bishop MD, Torres-Cueco R, Gay CW, Lluch-Girbés E, Beneciuk JM, Bialosky JE. What effect can manual therapy have on a patient's pain experience? Pain Manag. 2015;5(6):455-464.

103. Vigotsky AD, Bruhns RP. The role of descending modulation in manual therapy and its analgesic implications: a narrative review. Pain Res Treat. 2015;2015:292805.

104. Bartsch T, Goadsby PJ. Increased responses in trigeminocervical nociceptive neurons to cervical input after stimulation of the dura mater. Brain. 2003;126(Pt 8):1801-1813.

105. Zafar H, Nordh E, Eriksson PO. Temporal coordination between mandibular and head-neck movements during jaw opening-closing tasks in man. Arch Oral Biol. 2000;45(8):675-682.

106. Eriksson PO, Zafar H, Nordh E. Concomitant mandibular and headneck movements during jaw opening-closing in man. J Oral Rehabil. 1998;25(11):859-870. 
107. La Touche R, París-Alemany A, Mannheimer JS, et al. Does mobilization of the upper cervical spine affect pain sensitivity and autonomic nervous system function in patients with cervico-craniofacial pain? A randomized-controlled trial. Clin J Pain. 2013;29(3):205-215.

108. Gross AR, Kay TM, Kennedy C, et al. Clinical practice guideline on the use of manipulation or mobilization in the treatment of adults with mechanical neck disorders. Man Ther. 2002;7(4):193-205.

109. Assendelft WJ, Bouter LM, Knipschild PG. Complications of spinal manipulation: a comprehensive review of the literature. J Fam Pract. 1996;42(5):475-480.

110. Gross A, Miller J, D’Sylva J, et al. Manipulation or mobilisation for neck pain. Cochrane Database Syst Rev. 2010;(1):CD004249.

111. Crockett DJ, Foreman ME, Alden L, Blasberg B. A comparison of treatment modes in the management of myofascial pain dysfunction syndrome. Biofeedback Self Regul. 1986;11(4):279-291.

112. Niemelä K, Korpela M, Raustia A, Ylöstalo P, Sipilä K. Efficacy of stabilisation splint treatment on temporomandibular disorders. J Oral Rehabil. 2012;39(11):799-804.

113. Maloney GE, Mehta N, Forgione AG, Zawawi KH, Al-Badawi EA, Driscoll SE. Effect of a passive jaw motion device on pain and range of motion in TMD patients not responding to flat plane intraoral appliances. Cranio. 2002;20(1):55-66.

114. Magnusson T, Syrén M. Therapeutic jaw exercises and interocclusal appliance therapy: a comparison between two common treatments of temporomandibular disorders. Swed Dent J. 1999;23(1):27-37.

115. Michelotti A, Steenks MH, Farella M, Parisini F, Cimino R, Martina $\mathrm{R}$. The additional value of a home physical therapy regimen versus patient education only for the treatment of myofascial pain of the jaw muscles: short-term results of a randomized clinical trial. J Orofac Pain. 2004;18(2):114-125.

116. Craane B, Dijkstra PU, Stappaerts K, De Laat A. One-year evaluation of the effect of physical therapy for masticatory muscle pain: a randomized controlled trial. Eur J Pain. 2012;16(5):737-747.

117. Raustia AM, Pohjola RT. Acupuncture compared with stomatognathic treatment for TMJ dysfunction - part III: effect of treatment on mobility. J Prosthet Dent. 1986;56(5):616-623.

118. Lee MH, Park SJ, Kim JS. Effects of neck exercise on high-school students' neck-shoulder posture. JPhys Ther Sci. 2013;25(5):571-574.

119. Gupta BD, Aggarwal S, Gupta B, Gupta M, Gupta N. Effect of deep cervical flexor training vs. conventional isometric training on forward head posture, pain, neck disability index in dentists suffering from chronic neck pain. J Clin Diagnostic Res. 2013;7(10):2261-2264.

120. Kim JY, Kwag KI. Clinical effects of deep cervical flexor muscle activation in patients with chronic neck pain. J Phys Ther Sci. 2016;28(1): 269-273.

121. Miller J, Gross A, D’Sylva J, et al. Manual therapy and exercise for neck pain: a systematic review. Man Ther. 2010;15(4):334-354.

122. Takai Y, Yamamoto-Mitani N, Abe Y, Suzuki M. Literature review of pain management for people with chronic pain. Jpn J Nurs Sci. 2015;12(3):167-183.

123. O'Riordan C, Clifford A, van de Ven P, Nelson J. Chronic neck pain and exercise interventions: frequency, intensity, time, and type principle. Arch Phys Med Rehabil. 2014;95(4):770-783.

124. Geneen LJ, Moore RA, Clarke C, Martin D, Colvin LA, Smith BH. Physical activity and exercise for chronic pain in adults: an overview of Cochrane reviews. Cochrane Database Syst Rev. 2017;4:CD011279.

125. Rhodes RE, Janssen I, Bredin SS, Warburton DE, Bauman A. Physical activity: health impact, prevalence, correlates and interventions. Psychol Health. 2017;32(8):942-975.

126. Fernández-Carnero J, La Touche R, Ortega-Santiago R, et al. Shortterm effects of dry needling of active myofascial trigger points in the masseter muscle in patients with temporomandibular disorders. J Orofac Pain. 2010;24(1):106-12.

127. González-Iglesias J, Cleland JA, Neto F, Hall T, Fernández-de-lasPeñas C. Mobilization with movement, thoracic spine manipulation, and dry needling for the management of temporomandibular disorder: a prospective case series. Physiother Theory Pract. 2013;29(8):586-595.
128. Gonzalez-Perez LM, Infante-Cossio P, Granados-Nunez M, UrrestiLopez FJ, Lopez-Martos R, Ruiz-Canela-Mendez P. Deep dry needling of trigger points located in the lateral pterygoid muscle: efficacy and safety of treatment for management of myofascial pain and temporomandibular dysfunction. Med Oral Patol Oral Cir Bucal. 2015;20(3):e326-e333.

129. Blasco-Bonora PM, Martín-Pintado-Zugasti A. Effects of myofascial trigger point dry needling in patients with sleep bruxism and temporomandibular disorders: a prospective case series. Acupunct Med. 2017;35(1):69-74.

130. Simons DG, Travell JG. Myofascial Pain and Dysfunction: The Trigger Point Manual. Vol 1. Baltimore: Williams \& Wilkins; 1999.

131. Venâncio RA, Alencar FG, Zamperini C. Different substances and dry-needling injections in patients with myofascial pain and headaches. Cranio. 2008;26(2):96-103.

132. Jung A, Shin BC, Lee MS, Sim H, Ernst E. Acupuncture for treating temporomandibular joint disorders: a systematic review and meta-analysis of randomized, sham-controlled trials. J Dent. 2011;39(5):341-350.

133. Wu JY, Zhang C, Xu YP, et al. Acupuncture therapy in the management of the clinical outcomes for temporomandibular disorders. Medicine (Baltimore). 2017;96(9):e6064.

134. Cheng RS, Pomeranz B. Electroacupuncture analgesia could be mediated by at least two pain-relieving mechanisms; endorphin and non-endorphin systems. Life Sci. 1979;25(23):1957-1962.

135. Tsai HY, Lin JG, Inoki R. Further evidence for possible analgesic mechanism of electroacupuncture: effects on neuropeptides and serotonergic neurons in rat spinal cord. Jpn J Pharmacol. 1989;49(2):181-185.

136. Han Z, Jiang YH, Wan Y, Wang Y, Chang JK, Han JS. Endomorphin-1 mediates $2 \mathrm{~Hz}$ but not $100 \mathrm{~Hz}$ electroacupuncture analgesia in the rat. Neurosci Lett. 1999;274(2):75-78.

137. Mendelson $\mathrm{G}$. The possible role of enkephalin in the mechanism of acupuncture analgesia in man. Med Hypotheses. 1977;3(4):144-145.

138. Pomeranz B, Chiu D. Naloxone blockade of acupuncture analgesia: endorphin implicated. Life Sci. 1976;19(11):1757-1762.

139. Lu J, Shao RH, Hu L, Tu Y, Guo JY. Potential antiinflammatory effects of acupuncture in a chronic stress model of depression in rats. Neurosci Lett. 2016;618:31-38.

140. Kavoussi B, Ross BE. The neuroimmune basis of anti-inflammatory acupuncture. Integr Cancer Ther. 2007;6(3):251-257.

141. La Touche R, Angulo-Díaz-Parreño S, de-la-Hoz JL, et al. Effectiveness of Acupuncture in the treatment of temporomandibular disorders of muscular origin: a systematic review of the last decade. J Altern Complement Med. 2010;16(1):107-112.

142. La Touche R, Goddard G, De-La-Hoz JL, et al. Acupuncture in the treatment of pain in temporomandibular disorders: a systematic review and meta-analysis of randomized controlled trials. Clin J Pain. 2010;26(6):541-550.

143. Goddard G, Karibe H, McNeill C, Villafuerte E. Acupuncture and sham acupuncture reduce muscle pain in myofascial pain patients. J Orofac Pain. 2002;16(1):71-76.

144. Sekido R, Ishimaru K, Sakita M. Differences of electroacupunctureinduced analgesic effect in normal and inflammatory conditions in rats. Am J Chin Med. 2003;31(6):955-965.

145. Diraçoğlu D, Vural M, Karan A, Aksoy C. Effectiveness of dry needling for the treatment of temporomandibular myofascial pain: a doubleblind, randomized, placebo controlled study. J Back Musculoskelet Rehabil. 2012;25(4):285-290.

146. Chen J, Huang Z, Ge M, Gao M. Efficacy of low-level laser therapy in the treatment of TMDs: a meta-analysis of 14 randomised controlled trials. J Oral Rehabil. 2015;42(4):291-299.

147. Sakurai Y, Yamaguchi M, Abiko Y. Inhibitory effect of low-level laser irradiation on LPS-stimulated prostaglandin E2 production and cyclooxygenase-2 in human gingival fibroblasts. Eur J Oral Sci. 2000;108(1):29-34.

148. Aggarwal VR, Lovell K, Peters S, Javidi H, Joughin A, Goldthorpe J. Psychosocial interventions for the management of chronic orofacial pain. Cochrane Database Syst Rev. 20119;(11):CD008456. 
149. Liu HX, Liang QJ, Xiao P, Jiao HX, Gao Y, Ahmetjiang A. The effectiveness of cognitive-behavioural therapy for temporomandibular disorders: a systematic review. J Oral Rehabil. 2012;39(1):55-62.

150. Kotiranta U, Suvinen T, Forssell H. Tailored treatments in temporomandibular disorders: where are we now? A systematic qualitative literature review. J Oral Facial Pain Headache. 2014;28(1): 28-37.

151. Randhawa K, Bohay R, Côté P, et al. The effectiveness of noninvasive interventions for temporomandibular disorders. Clin J Pain. 2016;32(3):260-278.

152. Michelotti A, Iodice G, Vollaro S, Steenks MH, Farella M. Evaluation of the short-term effectiveness of education versus an occlusal splint for the treatment of myofascial pain of the jaw muscles. J Am Dent Assoc. 2012;143(1):47-53.

153. Wright EF, Domenech MA, Fischer JR. Usefulness of posture training for patients with temporomandibular disorders. J Am Dent Assoc. 2000;131(2):202-210.

154. Louw A, Zimney K, Puentedura EJ, Diener I. The efficacy of pain neuroscience education on musculoskeletal pain: a systematic review of the literature. Physiother Theory Pract. 2016;32(5):332-355.

155. Zhang Y, Montoya L, Ebrahim S, et al. Hypnosis/relaxation therapy for temporomandibular disorders: a systematic review and metaanalysis of randomized controlled trials. J Oral Facial Pain Headache. 2015;29(2):115-125.

156. Harper DE, Schrepf A, Clauw DJ. Pain mechanisms and centralized pain in temporomandibular disorders. J Dent Res. 2016;95(10):1102-1108.

157. La Touche R, Paris-Alemany A, Hidalgo-Pérez A, López-de-UraldeVillanueva I, Angulo-Diaz-Parreño S, Muñoz-García D. Evidence for central sensitization in patients with temporomandibular disorders: a systematic review and meta-analysis of observational studies. Pain Pract. Epub 2017 May 29.

158. Jones GT. Psychosocial vulnerability and early life adversity as risk factors for central sensitivity syndromes. Curr Rheumatol Rev. 2016;12(2):140-153.

159. Mansour AR, Farmer MA, Baliki MN, Apkarian AV. Chronic pain: the role of learning and brain plasticity. Restor Neurol Neurosci. 2014;32(1):129-139.

160. Adams LM, Turk DC. Psychosocial factors and central sensitivity syndromes. Curr Rheumatol Rev. 2015;11(2):96-108.

161. Soares GM, Rizzatti-Barbosa CM. Chronicity factors of temporomandibular disorders: a critical review of the literature. Braz Oral Res. Epub 2015 Jan 13.

162. La Touche R, Paris-Alemany A, Gil-Martínez A, Pardo-Montero J, Angulo-Díaz-Parreño S, Fernández-Carnero J. Masticatory sensorymotor changes after an experimental chewing test influenced by pain catastrophizing and neck-pain-related disability in patients with headache attributed to temporomandibular disorders. J Headache Pain. 2015;16:20.

163. Velly AM, Look JO, Carlson C, et al. The effect of catastrophizing and depression on chronic pain: a prospective cohort study of temporomandibular muscle and joint pain disorders. Pain. 2011;152(10):2377-2383.

164. Fillingim RB, Ohrbach R, Greenspan JD, et al. Psychological factors associated with development of TMD: the OPPERA prospective cohort study. J Pain. 2013;14(12 Suppl):T75-T90.

165. Gil-Martínez A, Navarro-Fernández G, Mangas-Guijarro MA, et al. Comparison between chronic migraine and temporomandibular disorders in pain-related disability and fear-avoidance behaviors. Pain Med. 2017;18(11):2214-2223.

166. Gil-Martínez A, Grande-Alonso M, López-de-Uralde-Villanueva I, López-López A, Fernández-Carnero J, La Touche R. Chronic temporomandibular disorders: disability, pain intensity and fear of movement. J Headache Pain. 2016;17(1):103.

167. Galli U, Ettlin DA, Palla S, Ehlert U, Gaab J. Do illness perceptions predict pain-related disability and mood in chronic orofacial pain patients? A 6-month follow-up study. Eur J Pain. 2010;14(5):550-558.
168. Su N, Lobbezoo F, van Wijk A, van der Heijden GJ, Visscher CM. Associations of pain intensity and pain-related disability with psychological and socio-demographic factors in patients with temporomandibular disorders: a cross-sectional study at a specialised dental clinic. J Oral Rehabil. 2017;44(3):187-196.

169. Luo X, Pietrobon R, Sun SX, Liu GG, Hey L. Estimates and patterns of direct health care expenditures among individuals with back pain in the United States. Spine (Phila Pa 1976). 2004;29(1):79-86.

170. Dıraçoğlu D, Yıldırım NK, Saral İ, et al. Temporomandibular dysfunction and risk factors for anxiety and depression. J Back Musculoskelet Rehabil. 2016;29(3):487-491.

171. Brister H, Turner JA, Aaron LA, Mancl L. Self-efficacy is associated with pain, functioning, and coping in patients with chronic temporomandibular disorder pain. J Orofac Pain. 2006;20(2):115-124.

172. Turner JA, Whitney C, Dworkin SF, Massoth D, Wilson L. Do changes in patient beliefs and coping strategies predict temporomandibular disorder treatment outcomes? Clin J Pain. 1995;11(3):177-188.

173. Fillingim RB, Ohrbach R, Greenspan JD, et al. Potential psychosocial risk factors for chronic TMD: descriptive data and empirically identified domains from the OPPERA case-control study. J Pain. 2011;12(11 Suppl):T46-T60.

174. Riley JL, Myers CD, Currie TP, et al. Self-care behaviors associated with myofascial temporomandibular disorder pain. J Orofac Pain. 2007;21(3):194-202.

175. Grossi ML, Goldberg MB, Locker D, Tenenbaum HC. Reduced neuropsychologic measures as predictors of treatment outcome in patients with temporomandibular disorders. J Orofac Pain. 2001;15(4):329-339.

176. Bair E, Ohrbach R, Fillingim RB, et al. Multivariable modeling of phenotypic risk factors for first-onset TMD: the OPPERA prospective cohort study. J Pain. 2013;14(12):T102-T115.

177. Reid KI, Greene CS. Diagnosis and treatment of temporomandibular disorders: an ethical analysis of current practices. J Oral Rehabil. 2013;40(7):546-561.

178. Klasser GD, Greene CS. The changing field of temporomandibular disorders: what dentists need to know. J Can Dent Assoc. 2009;75(1):49-53.

179. Palla S. Biopsychosocial pain model crippled? J Orofac Pain. 2011; 25(4):289-290.

180. Carlson CR. Psychological considerations for chronic orofacial pain. Oral Maxillofac Surg Clin North Am. 2008;20(2):185-195.

181. Lund JP, Donga R, Widmer CG, Stohler CS. The pain-adaptation model: a discussion of the relationship between chronic musculoskeletal pain and motor activity. Can J Physiol Pharmacol. 1991;69(5):683-694.

182. Feuerstein M, Beattie P. Biobehavioral factors affecting pain and disability in low back pain: mechanisms and assessment. Phys Ther. 1995;75(4):267-280.

183. Sterling M, Jull G, Wright A. The effect of musculoskeletal pain on motor activity and control. J Pain. 2001;2(3):135-145.

184. Cote JN, Bement MK. Update on the relation between pain and movement: consequences for clinical practice. Clin J Pain. 2010;26(9):754-762.

185. Le Pera D, Graven-Nielsen T, Valeriani M, et al. Inhibition of motor system excitability at cortical and spinal level by tonic muscle pain. Clin Neurophysiol. 2001;112(9):1633-1641.

186. Korotkov A, Ljubisavljevic M, Thunberg J, et al. Changes in human regional cerebral blood flow following hypertonic saline induced experimental muscle pain: a positron emission tomography study. Neurosci Lett. 2002;335(2):119-123.

187. Maihöfner C, Baron R, DeCol R, et al. The motor system shows adaptive changes in complex regional pain syndrome. Brain. 2007; 130(Pt 10):2671-2687.

188. Vallence AM, Smith A, Tabor A, Rolan PE, Ridding MC. Chronic tension-type headache is associated with impaired motor learning. Cephalalgia. 2013;33(12):1048-1054. 
189. Weissman-Fogel I, Moayedi M, Tenenbaum HC, Goldberg MB, Freeman BV, Davis KD. Abnormal cortical activity in patients with temporomandibular disorder evoked by cognitive and emotional tasks. Pain. 2011;152(2):384-396.

190. Salomons TV, Moayedi M, Weissman-Fogel I, et al. Perceived helplessness is associated with individual differences in the central motor output system. Eur J Neurosci. 2012;35(9):1481-1487.

191. Tucker K, Larsson AK, Oknelid S, Hodges P. Similar alteration of motor unit recruitment strategies during the anticipation and experience of pain. Pain. 2012;153(3):636-643.

192. Moseley GL, Nicholas MK, Hodges PW. Does anticipation of back pain predispose to back trouble? Brain. 2004;127(Pt 10):2339-2347.

193. Keefe F, Block A. Development of an observational method for assessing pain behavior in chronic pain patients. Behav Ther. 1982;13:363-375.

194. Prkachin K, Craig K. Expressing pain: the communication and interpretation of pain signals. J Nonverbal Behav. 1995;19:191-192.

195. Sullivan MJ. Toward a biopsychomotor conceptualization of pain: implications for research and intervention. Clin J Pain. 2008;24(4):281-290.

196. Verbunt JA, Sieben JM, Seelen HA, et al. Decline in physical activity, disability and pain-related fear in sub-acute low back pain. Eur J Pain. 2005;9(4):417-425.

197. Leeuw M, Goossens ME, Linton SJ, Crombez G, Boersma K, Vlaeyen JW. The fear-avoidance model of musculoskeletal pain: current state of scientific evidence. J Behav Med. 2007;30(1):77-94.

198. Bahat HS, Weiss PL, Sprecher E, Krasovsky A, Laufer Y. Do neck kinematics correlate with pain intensity, neck disability or with fear of motion? Man Ther. 2014;19(3):252-258.

199. Geisser ME, Haig AJ, Wallbom AS, Wiggert EA. Pain-related fear, lumbar flexion, and dynamic EMG among persons with chronic musculoskeletal low back pain. Clin J Pain. 2004;20(2):61-69.

200. George SZ, Fritz JM, McNeil DW. Fear-avoidance beliefs as measured by the fear-avoidance beliefs questionnaire: change in fear-avoidance beliefs questionnaire is predictive of change in self-report of disability and pain intensity for patients with acute low back pain. Clin J Pain. 2006;22(2): 197-203.

201. Thomas JS, France CR. Pain-related fear is associated with avoidance of spinal motion during recovery from low back pain. Spine (Phila Pa 1976). 2007;32(16):E460-E466.

202. Vlaeyen JW, Linton SJ. Fear-avoidance and its consequences in chronic musculoskeletal pain: a state of the art. Pain. 2000;85(3):317-332.

203. Van Damme S, Kindermans H. A self-regulation perspective on avoidance and persistence behavior in chronic pain: new theories, new challenges? Clin J Pain. 2015;31(2):115-122.

204. Simmonds MJ, Moseley GL, Vlaeyen JW. Pain, mind, and movement: an expanded, updated, and integrated conceptualization. Clin J Pain. 2008;24(4):279-280.
205. Sullivan MJ, Rodgers WM, Wilson PM, Bell GJ, Murray TC, Fraser SN. An experimental investigation of the relation between catastrophizing and activity intolerance. Pain. 2002;100(1-2):47-53.

206. Asghari A, Nicholas MK. Pain self-efficacy beliefs and pain behaviour: a prospective study. Pain. 2001;94(1):85-100.

207. Sardá J, Nicholas MK, Asghari A, Pimenta CA. The contribution of self-efficacy and depression to disability and work status in chronic pain patients: a comparison between Australian and Brazilian samples. Eur J Pain. 2009;13(2):189-195.

208. Luomajoki H, Kool J, de Bruin ED, Airaksinen O. Improvement in low back movement control, decreased pain and disability, resulting from specific exercise intervention. Sports Med Arthrosc Rehabil Ther Technol. 2010;2:11.

209. Koltyn KF. Exercise-induced hypoalgesia and intensity of exercise. Sports Med. 2002;32(8):477-487.

210. Koltyn KF. Analgesia following exercise: a review. Sports Med. 2000;29(2):85-98.

211. Koltyn KF, Brellenthin AG, Cook DB, Sehgal N, Hillard C. Mechanisms of exercise-induced hypoalgesia. J Pain. 2014;15(12):1294-1304.

212. Amiri SA, Bandpei MA, Javanshir K, Rezasoltani A, Biglarian A. The effect of different exercise programs on size and function of deep cervical flexor muscles in patients with chronic nonspecific neck pain Am J Phys Med Rehabil. 2017;96(8):582-588.

213. Bertozzi L, Gardenghi I, Turoni F, et al. Effect of therapeutic exercise on pain and disability in the management of chronic nonspecific neck pain: systematic review and meta-analysis of randomized trials. Phys Ther. 2013;93(8):1026-1036.

214. Saragiotto BT, Maher CG, Yamato TP, et al. Motor control exercise for chronic non-specific low-back pain. Cochrane Database Syst Rev. 2016;(1):CD012004.

215. Shire AR, Stæhr TA, Overby JB, Dahl MB, Jacobsen JS, Christiansen DH. Specific or general exercise strategy for subacromial impingement syndrome: does it matter? A systematic literature review and meta analysis. BMC Musculoskelet Disord. 2017;18(1):158, doi: 10.1186/ s12891-017-1518-0.

216. Gil-Martínez A, Kindelan-Calvo P, Agudo-Carmona D, Muñoz-Plata R, López-de-Uralde-Villanueva I, La Touche R. [Therapeutic exercise as treatment for migraine and tension-type headaches: a systematic review of randomised clinical trials]. Rev Neurol. 2013;57(10):433443. Spanish

217. López-de-Uralde-Villanueva I, Muñoz-García D, Gil-Martínez A, et al. A systematic review and meta-analysis on the effectiveness of graded activity and graded exposure for chronic nonspecific low back pain. Pain Med. 2015;17(1):172-188.

218. de Freitas RF, Ferreira MA, Barbosa GA, Calderon PS. Counselling and self-management therapies for temporomandibular disorders: a systematic review. J Oral Rehabil. 2013;40(11):864-874.

\section{Journal of Pain Research}

\section{Publish your work in this journal}

The Journal of Pain Research is an international, peer reviewed, open access, online journal that welcomes laboratory and clinical findings in the fields of pain research and the prevention and management of pain. Original research, reviews, symposium reports, hypothesis formation and commentaries are all considered for publication.

\section{Dovepress}

The manuscript management system is completely online and includes a very quick and fair peer-review system, which is all easy to use. Visit http://www.dovepress.com/testimonials.php to read real quotes from published authors. 